\title{
Analisis Persepsi Mahasiswa Pendidikan Geografi Terhadap Pelaksanaan Ujian Berbasis Online pada Mata Kuliah Statistik
}

\author{
Ade Wiranda, Darlina Siallagan, Nabila Anggraini, Nelvi Murniwati Mendrofa, \\ Sania Mutia, Rasni Arihta Siboro \\ Jurusan Pendidikan Geografi, Fakultas Ilmu Sosial, Universitas Negeri Medan \\ Jl. Willem Iskandar Pasar V Medan \\ Email : nabilaanggraini@mhs.unimed.ac.id
}

\begin{abstract}
The purpose of this study was to determine the perception of 2017 Geography Education Department students of the Faculty of Social Sciences, Medan State University, on the implementation of online-based examinations in the Statistics course. This research is a descriptive study, with the population being all students of the 2017 Geography Education Department, Medan State University. Sampling in this study used a purposive sampling technique, where the sample in this study were all C class students of the 2017 Geography Education Department, Faculty of Social Sciences, Medan State University, totaling 26 students. Data collection techniques through the distribution of questionnaires (questionnaires) to respondents, then the data were analyzed through several stages, namely editing, coding, scoring, and measuring perceptions with the interval scale method, the mean value, mean, median, mode, and standard deviation. The results of this study are to show that the perception of Class C students of the Department of Geography Education on the implementation of online-based exams in the Statistics subject is good or has a positive value.
\end{abstract}

Keywords: Perception, online exams, and statistics

\begin{abstract}
Abstrak
Tujuan dari penelitian ini adalah untuk mengetahui persepsi mahasiswa Jurusan Pendidikan Geografi Angkatan 2017 Fakultas Ilmu Sosial Universitas Negeri Medan terhadap pelaksanaan ujian berbasis online pada mata kuliah Statistik. Penelitian ini merupakan penelitian deskriptif, dengan populasi adalah seluruh mahasiswa Jurusan Pendidikan Geografi Angkatan 2017 Universitas Negeri Medan. Pengambilan sampel dalam penelitian ini menggunakan teknik purposive sampling, dimana sampel dalam penelitian ini adalah seluruh mahasiswa kelas C Jurusan Pendidikan Geografi Angkatan 2017 Fakultas Ilmu Sosial Universitas Negeri Medan sebanyak 26 mahasiswa. Teknik pengumpulan data dengan melalui penyebaran kuesioner (angket) kepada responden, kemudian data dianalisis melalui beberapa tahap yaitu editing, coding, scoring, dan pengukuran persepsi dengan metode skala interval, nilai rata-rata (mean), median, modus, dan standar deviasi. Hasil penelitian ini adalah menunjukkan bahwasanya persepsi mahasiswa kelas $C$ Jurusan Pendidikan Geografi terhadap pelaksanaan ujian berbasis online pada mata kuliah Statistik adalah baik atau bernilai positif.
\end{abstract}

Kata Kunci: Persepsi, ujian online, dan statistik

\section{PENDAHULUAN}

Kemajuan ilmu pengetahuan dan teknologi (IPTEK), khususnya teknologi informasi dan komunikasi (Information and Communication Technology, ICT), demikian pesat (Budiman, 2017). 
Kemajuan ini tentu saja berpengaruh terhadap berbagai bidang kehidupan, termasuk di dalamnya pendidikan. Salah satu penerapan ICT dalam pendidikan adalah dengan diterapkannya pembelajaran melalui jaringan Internet, yang dikenal dengan e-learning. E-learning mengacu pada belajar dengan menggunakan sarana komputer yang berbasis pada teknologi Internet (Julaeha \& Padmo, 2007). E-learning (belajar berbasis jaringan elektronik) mengacu pada pembelajaran online (Soekartawi \& Librero, 2002).

Dalam mewujudkan sebuah e-learning sistem yang efisien maka diperlukan sebuah mekanisme untuk mengidentifikasi pengetahuan yang telah diperoleh peserta terhadap materi yang sudah diberikan oleh sistem e-learning (Darmayanti, Setiani, \& Oetojo, 2007). Identifikasi pengetahuan peserta dapat dilakukan dengan adanya suatu sistem ujian atau asessment. Untuk mengakomodasi asessment pada sistem $e$ learning dapat dilakukan dengan computerized asessment atau ujian terkomputerisasi yang berbasiskan komputer, disebut juga CBT (Computer Based Test) baik itu terhubung internet (online) atau tidak.

Pada Jurusan Pendidikan Geografi Universitas Negeri Medan, sistem pembelajaran dalam jaringan telah diterapkan dalam beberapa tahun belakangan ini. Salah satu penggunaannya adalah dengan menerapkan Blog dalam pembelajaran (Damanik \& Nurman, 2016). Pada tahun 2018, penerapan pembelajaran dalam jaringan ini lebih diperkuat dengan menerapkan Sistem Pembelajaran Daring (SIPDA). Seluruh kegiatan pembelajaran yang dilakukan dengan memadukan $e$ learning dengan pembelajaran tatap muka. $\mathrm{Hal}$ ini terlihat pada mata kuliah Statistik, dimana pertama kali dilakukannya ujian tengah semester (UTS) dan ujian akhir semester (UAS) berbasis online pada mahasiswa kelas C Jurusan Pendidikan Geografi Angkatan 2017 Fakultas IImu Sosial. Tentunya, pelaksanaan ujian berbasis online memiliki beberapa kelebihan juga kelemahan dalam pelaksanaannya sehingga menyebabkan timbulnya persepsi mahasiswa terhadap ujian berbasis online tersebut. Persepsi yang muncul tidaklah mungkin dari satu mahasiswa dengan mahasiswa yang lainnya akan sama, tentunya persepsi yang timbul akan berbeda.

Perbedaan persepsi ini dapat disebabkan dari hasil ujian yang didapatkan mahasiswa dan pengalaman yang dirasakan mahasiswa setelah melaksanakan ujian berbasis online untuk pertama kalinya dalam perkuliahan Statistik. Tujuan penelitian ini adalah mengetahui pandangan mahasiswa terhadap pelaksanaan ujian berbasis online dan kecenderungan persepsi mahasiswa antara pro atau kontra terhadap pelaksanaan ujian tersebut.

\section{METODE PENELITIAN}

Jenis penelitian yang digunakan adalah penelitian deskriptif, yaitu penelitian yang berusaha mendeskripsikan suatu gejala, peristiwa, kejadian yang terjadi pada saat sekarang. (Sujana dan Ibrahim, 1989:65). Penelitian ini dilaksanakan di Jurusan Pendidikan Geografi Fakultas Ilmu Sosial Universitas Negeri Medan yang beralamatkan di JI Willem Iskandar Pasar V Medan, Sumatera Utara.

Populasi dalam penelitian ini adalah seluruh mahasiswa Jurusan Pendidikan Geografi Angkatan 2017 Universitas Negeri Medan. Pengambilan sampel dalam penelitian ini menggunakan teknik purposive sampling, dimana sampel dalam penelitian ini adalah seluruh mahasiswa kelas C Jurusan Pendidikan Geografi Angkatan 2017 Fakultas Ilmu Sosial Universitas Negeri Medan sebanyak 25 orang, mengingat hanya mahasiswa kelas $C$ yang telah melakukan ujian berbasis online pada mata kuliah Statistik. Teknik pengumpulan data dengan melalui penyebaran kuesioner (angket) kepada responden, kemudian data dianalisis melalui beberapa tahap yaitu editing, coding, scoring, dan pengukuran persepsi dengan metode skala interval, nilai ratarata (mean), median, modus, dan standar deviasi.

\section{HASIL DAN PEMBAHASAN \\ Mahasiswa Lebih Senang Mengikuti Ujian Berbasis Online Pada Mata Kuliah Statistik}

Hasil analisis menunjukkan bahwa sebanyak 22 mahasiswa atau $88 \%$ dari 
seluruh responden menyatakan mereka lebih senang melaksanakan pelaksanaan ujian online pada Ujian Tengah Semester (UTS) dan Ujian Akhir Semester (UAS) mata kuliah Statistik, sebanyak 1 mahasiswa atau $4 \%$ menyatakan ragu-ragu, serta 2 mahasiswa atau $8 \%$ menyatakan tidak. Hasil skor rata-rata (mean) mahasiswa yang lebih senang mengikuti pelaksanaan ujian online adalah 2,8. Skor ini berada pada skala interval 2,42-3,12 yang menunjukkan persepsi mahasiswa Jurusan Pendidikan Geografi kelas C lebih senang melaksanakan ujian online pada mata kuliah Statistik adalah positif. Grafik Persepsi mahasiswa mengikuti ujian berbasis online dapat dilihat pada Gambar 1

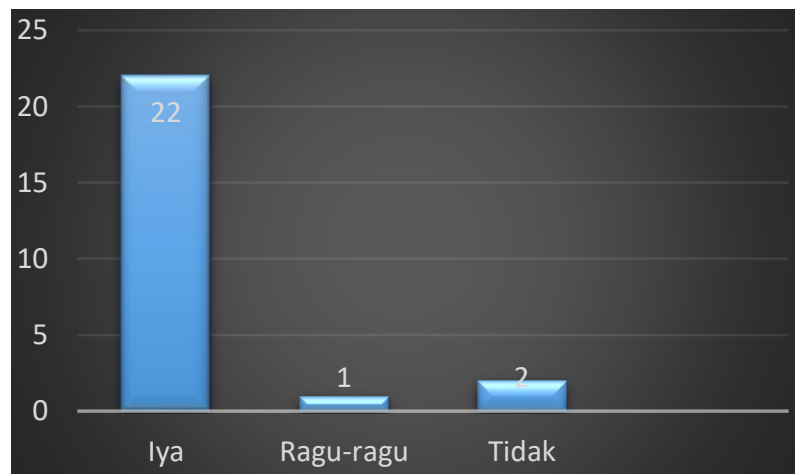

Gambar 1. Persepsi mahasiswa mengikuti ujian berbasis online pada mata kuliah Statistik berdasarkan tingkat kesenangan

\section{Mahasiswa Dapat Melaksanakan Ujian Berbasis Online Pada Mata Kuliah Statistik dengan Baik.}

Hasil analisis menunjukkan (Gambar 2) bahwa sebanyak 21 mahasiswa atau 84\% dari seluruh responden menyatakan mereka dapat melaksanakan pelaksanaan ujian online pada Ujian Tengah Semester (UTS) dan Ujian Akhir Semester (UAS) mata kuliah Statistik dengan baik, sebanyak 2 mahasiswa atau 8\% menyatakan ragu-ragu, serta 2 mahasiswa atau $8 \%$ menyatakan tidak. Hasil skor rata-rata (mean) mahasiswa yang mengikuti ujian online mata kuliah Statistik adalah 2,76. Skor ini berada pada skala interval 2,42-3,12 yang menunjukkan persepsi mahasiswa Jurusan Pendidikan Geografi kelas $\mathrm{C}$ lebih melaksanakan ujian online pada mata kuliah Statistik dengan baik adalah positif.

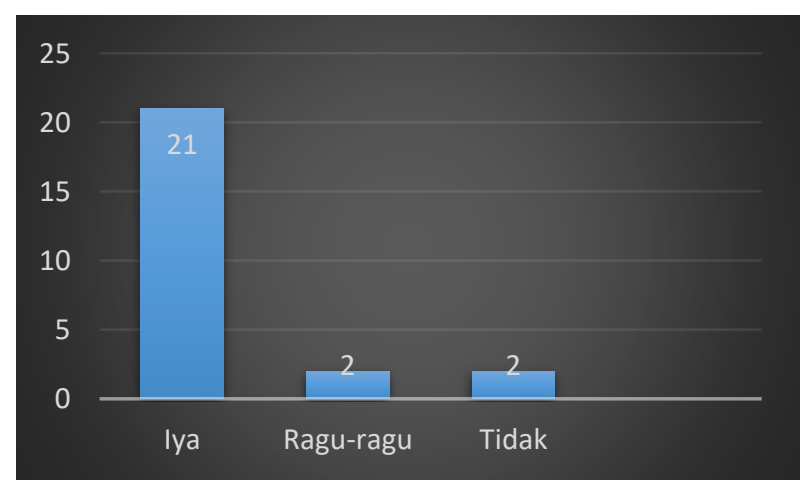

Gambar 2. Persepsi mahasiswa mengikuti ujian berbasis online pada mata kuliah Statistik dengan baik 


\section{Penerapan Ujian Berbasis Online Pada Mata Kuliah Statistik Bermanfaat Bagi Mahasiswa}

Pada Gambar 3 dapat dilihat bahwa sebanyak 23 mahasiswa atau 92\% dari seluruh responden menyatakan ujian berbasis online pada mata kuliah Statistik bermanfaat bagi mahasiswa, sebanyak 0 mahasiswa atau $0 \%$ menyatakan raguragu, serta 2 mahasiswa atau $8 \%$ menyatakan tidak. Hasil skor rata-rata (mean) mahasiswa yang menyatakan penerapan ujian berbasis online pada mata kuliah Statistik bermanfaat bagi mahasiswa adalah 2,84. Skor ini berada pada skala interval 2,42-3,12 yang menunjukkan persepsi mahasiswa Jurusan Pendidikan Geografi kelas $C$ bahwa penerapan ujian berbasis online pada mata kuliah Statistik bermanfaat bagi mahasiswa adalah positif.

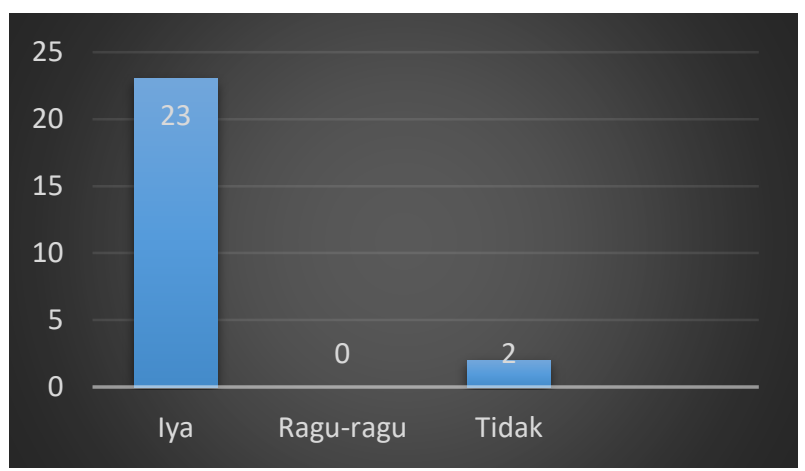

Gambar 3. Persepsi terhadap penerapan ujian berbasis online pada mata kuliah statistik bermanfaat bagi mahasiswa

\section{Mahasiswa Mengalami Kesulitan Dalam Pelaksanaan Ujian Berbasis Online Pada Mata Kuliah Statistik}

Gambar 4 menunjukkan bahwa sebanyak 10 mahasiswa atau $40 \%$ dari seluruh responden menyatakan bahwa mahasiswa mengalami kesulitan dalam pelaksanan ujian berbasis online, sebanyak 7 mahasiswa atau $25 \%$ menyatakan raguragu, serta 8 mahasiswa atau 32\% menyatakan tidak. Hasil skor rata-rata (mean) mahasiswa yang menyatakan penerapan ujian berbasis online pada mata kuliah Statistik bermanfaat bagi mahasiswa adalah 2,08. Skor ini berada pada skala interval 1,71-2,41 yang menunjukkan persepsi mahasiswa Jurusan Pendidikan Geografi kelas $C$ bahwa mahasiswa merasa kesulitan dalam pelaksanaan ujian berbasis online pada mata kuliah Statistik adalah sedang.

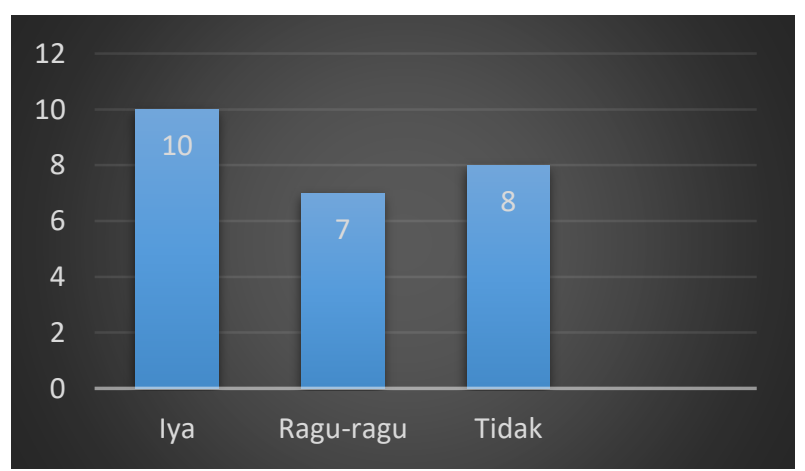

Gambar 4. Persepsi Mahasiswa Mengalami Kesulitan Dalam Pelaksanaan Ujian Berbasis Online Pada Mata Kuliah Statistik 
Sarana prasarana yang dimiliki oleh Jurusan Pendidikan Geografi mendukung dalam pelaksanaan ujian berbasis online pada mata kuliah Statistik

Grafik 5 yang menunjukkan bahwa sebanyak 17 mahasiswa atau $68 \%$ dari seluruh responden menyatakan sarana dan prasarana Jurusan Pendidikan Geografi sudah mendukung untuk pelaksanaan ujian online, sebanyak 1 mahasiswa atau $4 \%$ menyatakan ragu-ragu, serta 7 mahasiswa atau $28 \%$ menyatakan tidak. Hasil skor rata-rata (mean) mahasiswa yang menyatakan sarana dan prasarana Jurusan Pendidikan Geografi sudah mendukung untuk pelaksanaan ujian online adalah 2,4. Skor ini berada pada skala interval 1,71-2,41 yang menunjukkan persepsi mahasiswa Jurusan Pendidikan Geografi kelas $C$ bahwa sarana dan prasarana Jurusan Pendidikan Geografi sudah mendukung untuk pelaksanaan ujian online adalah sedang.

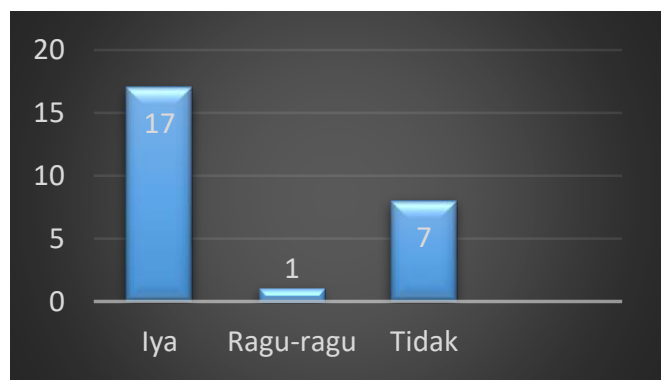

Gambar 5. Persepsi mahasiswa terhadap sarana prasarana yang dimiliki oleh Jurusan Pendidikan Geografi mendukung dalam pelaksanaan ujian berbasis online pada mata kuliah Statistik

\section{Ujian Berbasis Online Pada Mata Kuliah Statistik Dapat dijadikan Sebagai Contoh Pelaksanaan Pembelajaran E-Learning Di Universitas Negeri Medan}

Gambar 6 menunjukkan sebanyak 20 mahasiswa atau $80 \%$ dari seluruh responden menyatakan ujian berbasis online pada mata kuliah Statistik sebagai contoh pelaksanaan pembelajaran elearning di Universitas Negeri Medan, sebanyak 0 mahasiswa atau $0 \%$ menyatakan ragu-ragu, serta 5 mahasiswa atau $20 \%$ menyatakan tidak. Hasil skor rata-rata (mean) mahasiswa yang menyatakan sarana dan prasarana Jurusan Pendidikan Geografi sudah mendukung untuk pelaksanaan ujian online adalah 2,6. Skor ini berada pada skala interval 2,423,12 yang menunjukkan persepsi mahasiswa Jurusan Pendidikan Geografi kelas $C$ bahwa ujian berbasis online pada mata kuliah Statistik sebagai contoh pelaksanaan pembelajaran e-learning di Universitas Negeri Medan adalah positif.

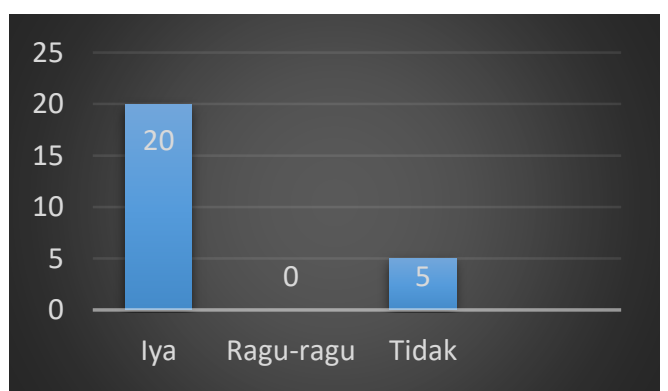

Gambar.6 Persepsi Mahasiswa Terhadap Ujian Berbasis Online Pada Mata Kuliah Statistik Dapat dijadikan Sebagai Contoh Pelaksanaan Pembelajaran E-Learning di Universitas Negeri Medan 


\section{Ujian Berbasis Online Pada Mata Kuliah Statistik Dapat Meminimalisir Kecurangan Dalam Ujian}

Gambar 7 menunjukkan bahwa sebanyak 17 mahasiswa atau 68\% dari seluruh responden menyatakan ujian berbasis online pada mata kuliah Statistik dapat meminimalisir kecurangan dalam ujian, sebanyak 5 mahasiswa atau $20 \%$ menyatakan ragu-ragu, serta 3 mahasiswa atau $12 \%$ menyatakan tidak. Hasil skor rata-rata (mean) mahasiswa yang menyatakan ujian berbasis online pada mata kuliah Statistik dapat meminimalisir kecurangan dalam ujian adalah 2,56. Skor ini berada pada skala interval 2,42-3,12 yang menunjukkan persepsi mahasiswa Jurusan Pendidikan Geografi kelas C bahwa pelaksanaan ujian berbasis online pada mata kuliah Statistik dapat meminimalisir kecurangan dalam ujian adalah positif.

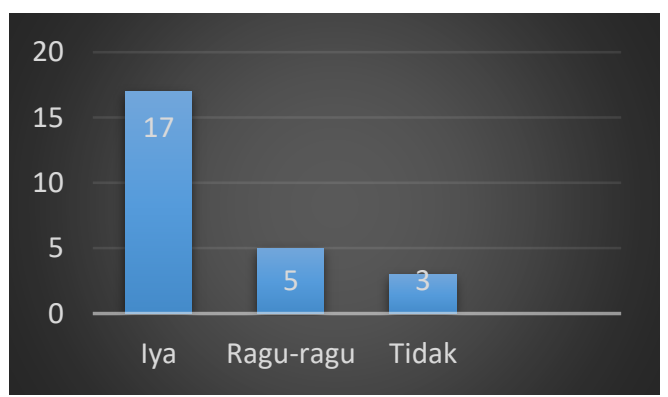

Gambar 7. Persepsi Mahasiswa Terhadap Ujian Berbasis Online Pada Mata Kuliah Statistik Dapat Meminimalisir Kecurangan Dalam Ujian

Pelaksanaan Ujian Berbasis Online Pada Mata Kuliah Statistik Lebih Efektif Dan Efisien Daripada Ujian Konvensional

Gambar 8 menunjukkan bahwa sebanyak 21 mahasiswa atau $84 \%$ dari seluruh responden menyatakan ujian berbasis online pada mata kuliah Statistik lebih efektif dan efisien daripada ujian konvensional, sebanyak 0 mahasiswa atau $0 \%$ menyatakan ragu-ragu, serta 4 mahasiswa atau $16 \%$ menyatakan tidak.
Hasil skor rata-rata (mean) mahasiswa yang menyatakan ujian berbasis online pada mata kuliah Statistik lebih efektif dan efisien daripada ujian konvensional adalah 2,56. Skor ini berada pada skala interval 2,423,12 yang menunjukkan persepsi mahasiswa Jurusan Pendidikan Geografi kelas $C$ bahwa pelaksanaan ujian berbasis online pada mata kuliah Statistik lebih efektif dan efesien daripada ujian konvensional adalah positif.

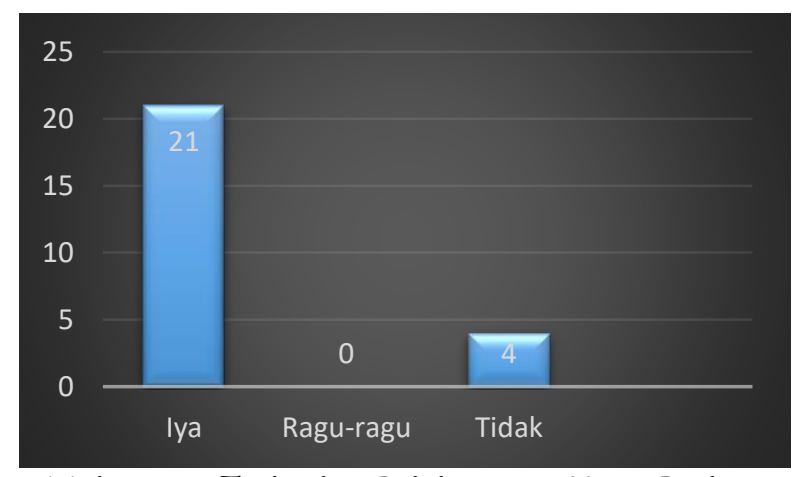

Gambar 8. Persepsi Mahasiswa Terhadap Pelaksanaan Ujian Berbasis Online Pada Mata Kuliah Statistik Lebih Efektif Dan Efisien Daripada Ujian Konvensional

\section{Mahasiswa Merasa Puas Dengan Pelaksanaan Ujian Berbasis Online Mata Kuliah Statistik}

Gambar 9 menunjukkan bahwa sebanyak 20 mahasiswa atau $80 \%$ dari seluruh responden menyatakan puas dengan pelaksanaan ujian berbasis online pada mata kuliah Statistik, sebanyak 0 mahasiswa atau $0 \%$ menyatakan raguragu, serta 5 mahasiswa atau $20 \%$ 
menyatakan tidak. Hasil skor rata-rata (mean) mahasiswa yang puas dengan pelaksanaan ujian berbasis online pada mata kuliah Statistik. adalah 2,6. Skor ini berada pada skala interval 2,42-3,12 yang menunjukkan persepsi mahasiswa Jurusan Pendidikan Geografi kelas C bahwa mahasiswa merasa puas dengan pelaksanaan ujian berbasis online pada mata kuliah Statistik adalah positif.

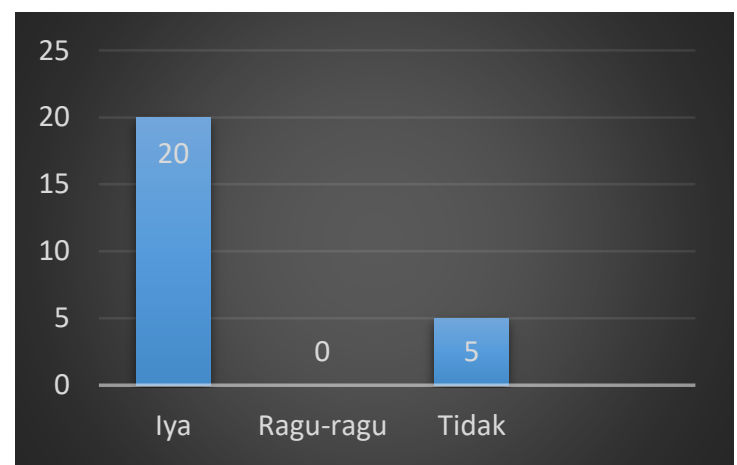

Gambar 9. Persepsi Mahasiswa Terhadap Pelaksanaan Ujian Berbasis Online Pada Mata Kuliah Statistik Lebih Efektif Dan Efisien Daripada Ujian Konvensional

Skor Rata-rata (Mean) Akhir Persepsi Mahasiswa Terhadap Pelaksanaan Ujian Berbasis Online Mata Kuliah Statistik

Dari analisis data yang disajikan pada gambar 10 dapat dilihat bahwa skor ratarata (mean) akhir dari jumlah keseluruhan data yang diperoleh adalah $14,92: 9=2,59$ yang berada pada skala interval 2,42-3,12 atau berkategori positif. Maka, dari pengolahan data dapat disimpulkan bahwa Persepsi Mahasiswa Kelas C Jurusan Pendidikan Geografi Terhadap Pelaksanaan Ujian Berbasis Online Pada Mata Kuliah Statistik adalah baik.
Median atau nilai tengah pada keseluruhan penilaian persepsi mahasiswa terhadap pelaksanaan ujian berbasis online pada mata kuliah Statistik sebesar 2,6 dan modus atau gambaran data yang paling banyak muncul pada keseluruhan penilaian persepsi mahasiswa terhadap pelaksanaan ujian berbasis online pada mata kuliah Statistik sebesar 2,595. Sedangkan simpangan baku atau standar deviasi terhadap penilaian persepsi mahasiswa terhadap pelaksanaan ujian berbasis online pada mata kuliah Statistik yaitu 0,27. Nilai ini menunjukkan bahwa hanya terdapat sangat sedikit variasi data yang telah didapat.

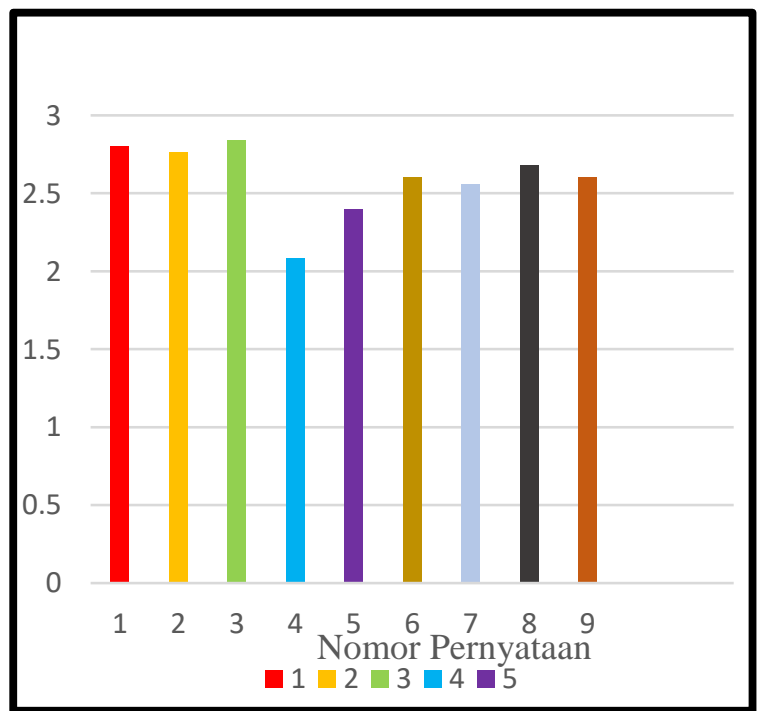

Gambar 10. Skor Rata-rata (Mean) Akhir Persepsi Mahasiswa Terhadap Pelaksanaan Ujian Berbasis Online Mata Kuliah Statistik 


\section{KESIMPULAN}

Skor rata-rata (mean) akhir dari jumlah keseluruhan data yang diperoleh adalah $14,92: 9=2,59$ yang berada pada skala interval 2,42-3,12 atau berkategori positif. Maka, dari pengolahan data dapat disimpulkan bahwa Persepsi Mahasiswa Kelas C Jurusan Pendidikan Geografi Terhadap Pelaksanaan Ujian Berbasis Online Pada Mata Kuliah Statistik adalah baik atau bernilai positif.

\section{DAFTAR PUSTAKA}

Budiman, H. (2017). Peran teknologi informasi dan komunikasi dalam pendidikan. Al-Tadzkiyyah: Jurnal Pendidikan Islam, 8(1), 31-43.

Damanik, M. R. S., \& Nurman, A. (2016). PEMANFAATAN BLOG PADA MATA
KULIAH SISTEM INFORMASI GEOGRAFI JURUSAN PENDIDIKAN GEOGRAFI FAKULTAS ILMU SOSIAL UNIVERSITAS NEGERI MEDAN. JURNAL GEOGRAFI, $8(1)$.

Darmayanti, T., Setiani, M. Y., \& Oetojo, B. (2007). E-learning pada pendidikan jarak jauh: konsep yang mengubah metode pembelajaran di perguruan tinggi di Indonesia. Jurnal Pendidikan Terbuka Dan Jarak Jauh, 8(2), 99-113.

Julaeha, S., \& Padmo, D. (2007). Tingkat Pemanfaatan E-learning Mahasiswa Universitas Terbuka. Majalah IImiah Pembelajaran, (1).

Soekartawi, A. H., \& Librero, F. (2002). Greater learning opportunities through distance education: experiences in Indonesia and the Philippines. Journal of Southeast Asian Education, 3(2), 283-320. 